\title{
TELIPOGON HELLERI (ORCHIDACEAE): POPULATION CHARACTERISTICS, NEW LOCALITY IN MEXICO AND RISK OF EXTINCTION
}

\author{
Alfredo García-González ${ }^{1,4}$, Anne Damon ${ }^{1}$, Frander B. Riverón-Giró¹, \\ Osiris Aguilar-Romero², Lislie Solís-Montero 1 and Irene Ávila-Díaz ${ }^{3}$ \\ ${ }^{1}$ El Colegio de la Frontera Sur, Unidad Tapachula, Tapachula, Chiapas, México. \\ ${ }^{2}$ Universidad Autónoma Metropolitana, Unidad Iztapalapa, Iztapalapa, Ciudad de México, México. \\ ${ }^{3}$ Universidad Michoacana de San Nicolás de Hidalgo, Facultad de Biología, Morelia, Michoacán, México. \\ ${ }^{4}$ Corresponding author: alfredmx22@gmail.com
}

\begin{abstract}
The first record of Telipogon helleri (Orchidaceae) in Mexico was in 2009. The relevance of this study is the finding and characterization of a second population of this taxon, in a new location, and the revaluation of the original population five years later of its discovery. In addition, we evaluated the new population by the Method of Evaluation of Risk of Extinction for plants in Mexico (MER-Plantas). We evaluated this species using the Risk Assessment Method of Extinction for plants in Mexico (MERPlantas). The original population increased $1.7 \%$ (15.38\% immatures; $84.62 \%$ adults; $\mathrm{n}=78$ individuals), and was distributed among six phorophytes (four more than in 2009), with $73.08 \%$ of the individuals growing on twigs and with a similar number of individuals facing the different cardinal points. The new population was found in a cloud forest fragment, growing on a single phorophyte (Brunellia mexicana), consisting of 36 individuals (38.89\% immatures; $61.11 \%$ adults), all of which were growing on the trunk and $69.44 \%$ facing west. We suggest that $T$. helleri should be placed in the category of endangered (P), in the Mexican Official Standard for threatened flora and fauna. It is necessary to carry out demographic and molecular studies to evaluate the levels of endogamy and the genetic viability of the individuals present and to estimate the capacity for adaptation and population growth. The increase in the number of individuals in the last five years could be rapidly reversed given the adverse conditions prevailing in the habitats and localities where the two populations are found.
\end{abstract}

Key words: Chiapas, cloud forest, coffee plantations, life classes, MER-Plantas, phorophyte, vertical distribution.

Resumen: El primer registro de Telipogon helleri (Orchidaceae) en México fue en 2009. En el presente estudio se informa del hallazgo de una segunda población de este taxón, en una nueva localidad, y se reevalúa la población original cinco años después de su descubrimiento. Además, se caracteriza la nueva población y se evalúa la especie a través del Método de Evaluación del Riesgo de Extinción para plantas en México (MER-Plantas). Actualmente la población original presenta un incremento de $1.7 \%$ (15.38 $\%$ inmaduros; $84.62 \%$ adultos; $\mathrm{n}=78$ individuos), crece sobre seis forófitos (cuatro más que en 2009), $73.08 \%$ de los individuos se encuentran sobre ramillas y su número hacia las diferentes orientaciones cardinales es similar. La nueva población de $T$. helleri se localizó en un fragmento de bosque de niebla, sobre un único forófito (Brunellia mexicana), cuenta con 36 individuos (38.89\% inmaduros; $61.11 \%$ adultos), todos crecían sobre el tronco y $69.44 \%$ lo hacía con orientación oeste. Se propone que la especie se considere en la categoría en peligro de extinción (P) en la Norma Oficial Mexicana. Es necesario realizar estudios demográficos y moleculares de $T$. helleri, para conocer los niveles de endogamia y variabilidad genética de los individuos y estimar la capacidad de adaptación y crecimiento poblacional de la especie. El aumento en el número de individuos que se ha logrado en los últimos cinco años podría invertirse rápidamente por las condiciones adversas de los hábitats y las localidades donde se encuentra.

Palabras clave: Bosque de niebla, cafetal, Chiapas, clases de vida, distribución vertical, forófito, MER-Plantas.

T he Orchidaceae is the largest and most diverse family of vascular epiphytes in the world (Fay and Chase, 2009), but is also one of the most threatened plant families (Dillon, 1977; IUCN and OSG, 2012). Mexico, located on the northern edge of the American tropics, harbors a remarkable orchid diversity, with approximately 1,260 species registered (60\% epiphytes) and 170 genera (Hágsater et al., 2005; Soto-Arenas et al., 2007). Of this great diversity of 
orchids, 188 species are included in a risk category in the Mexican Official Standard for Threatened Flora and Fauna (SEMARNAT, 2010).

Despite the systematic destruction of its ecosystems, 322 species of orchids have been registered in the region of Soconusco in the state of Chiapas, Mexico, of which more than 200 can still be found. The biological corridor TacanáBoquerón (Priority Terrestrial Region 135 designated by CONABIO; Arriaga et al., 2000), which covers a major part of the region of Soconusco, is known to be the second region with the greatest orchid species richness in Mexico (Solano-Gómez et al., 2016, in press).

Historically, a high proportion of Mexican orchids have found refuge in traditional shaded coffee plantations in various parts of the country, wherein 76 genera and 213 species have been registered. Of those, $180(84.1 \%)$ are classified as epiphytes, 31 (14.4\%) are terrestrials, and four can adapt to both epiphytic and terrestrial habits. Furthermore, 47 (22\%) of those species are endemic (Espejo-Serna et al., 2005).

One of the genera that has been found growing in coffee agroecosystems in Mexico is Telipogon Kunth, which are orchids of the subtribe Telipogoninae, with approximately 32 species worldwide (Ackerman, 2014). These plants are epiphytic or terrestrial and most grow in the cool, humid environments of cloud forests at high elevations from Central America to Bolivia, and in the Carribean (Dodson and Escobar, 1987; Ackerman, 2014). Telipogon helleri (L.O. Williams) N.H. Williams \& Dressler (Figure 1A, B), recently found in shaded coffee plantations in the region of Soconusco (Solano-Gómez et al., 2011; García-González and Damon, 2013), is a small epiphytic species with deciduous leaves and thick, succulent, slightly flattened roots. Flowering occurs from October to January, in which a single inflorescence is usually produced, carrying minute flowers measuring 4.5-5 $\mathrm{mm}$ in diameter, which open sequentially. The flowers have green-purple petals and sepals and a dark purple lip (Solano-Gómez et al., 2011).

In this study we inform of the discovery and characterization of a new population of Telipogon helleri in Mexico, in a different habitat to that in which the first population was found in 2009, and the reevaluation of the original population five years after its discovery (Solano-Gómez et al., 2011; García-González and Damon, 2013). We evaluated T. helleri by applying the Risk Assessment Method of Extinction for plants in Mexico (MER-Plantas).

\section{Materials and methods}

Search for new individuals of $\mathrm{T}$. helleri. Transects were set up of variable lengths depending upon the accessibility of the terrain, within the coffee plantation of the original population, and in the fragments of surrounding cloud forest; in total, approximately 4 ha were explored. The plants were located directly, or with the help of binoculars and all the phorophytes with $T$. helleri growing on them were identified. In this study the term phorophyte is only used for the trees and coffee bushes where T. helleri was found growing (García-González and Pérez-Márquez, 2011).

Site characterization. The study was carried out during the first six months of 2014, in the area surrounding the rural community of Benito Juárez El Plan (BJ), in the buffer zone of the Tacaná Volcano Biosphere Reserve, municipality of Cacahoatán, region of Soconusco, Chiapas, Mexico (Figure 2). The habitat of the original population was a plantation of shaded arabic coffee (Coffea arabica L.; Rubiaceae), of 25 year-old and with commercial polyculture system (Moguel and Toledo, 1999) (Locality 1; Figure 1C). The habitat of the new population was a fragment of cloud forest (Locality 2; Figure 1D). In the coffee plantation no agrochemicals were used, weeds were cleared twice a year, and shade trees were lightly pruned once a year. The fragment of cloud forest consisted of secondary vegetation at an advanced stage of succession, with very tall emergent trees. The coffee plantation was situated at $1,400 \mathrm{~m}$ a.s.l., with coordinates $15^{\circ} 5^{\prime} 15^{\prime \prime} \mathrm{N} ; 92^{\circ} 8^{\prime} 55^{\prime \prime} \mathrm{W}$, whereas the fragment of cloud forest was situated at 1,499 $\mathrm{m}$ a.s.l., with coordinates $15^{\circ} 5^{\prime} 16.38^{\prime \prime} \mathrm{N} ; 92^{\circ} 8^{\prime} 42.78^{\prime \prime} \mathrm{W}$. Annual rainfall and average temperatures in the area are $3,674.4 \mathrm{~mm}$ and $20.7^{\circ} \mathrm{C}$ respectively (SEMARNAT and CONANP, 2013).

Height and DBH of the phorophytes. The height and DBH (diameter at breast height) of all the phorophytes were measured in both populations. The height and diameter were also measured at the points where plants of Telipogon helleri were found growing, using the same methods as García-González et al. (2011) and García-González and Damon (2013).

Vertical distribution, life stages and orientation of the individuals of $\mathrm{T}$. helleri within the phorophytes. The zonation proposed by García-González et al. (2011) for coffee bushes and shade trees was used to determine the microsites (trunk, branch forks, branches or twigs) and vertical distribution of T. helleri. However, in the case of the phorophyte in Locality 2 , the twigs were also taken into account considering that, unlike the shade trees in coffee plantations, the trees in the cloud forest fragment were not subject to periodic pruning. The life stages and cardinal orientation were determined using the methods proposed by García-González and Damon (2013).

Evaluation of the risk status of $\mathrm{T}$. helleri. We used the Risk Assessment Method of Extinction for plants in Mexico (MER-Plantas; SEMARNAT, 2010), designed to be used to evaluate the risk status of any species of Mexican flora (Valverde et al., 2009), and is based on a combination of a rarity index (IR) and an index of anthropogenic impact (IIA), with the results indicating one of the following categories: En- 

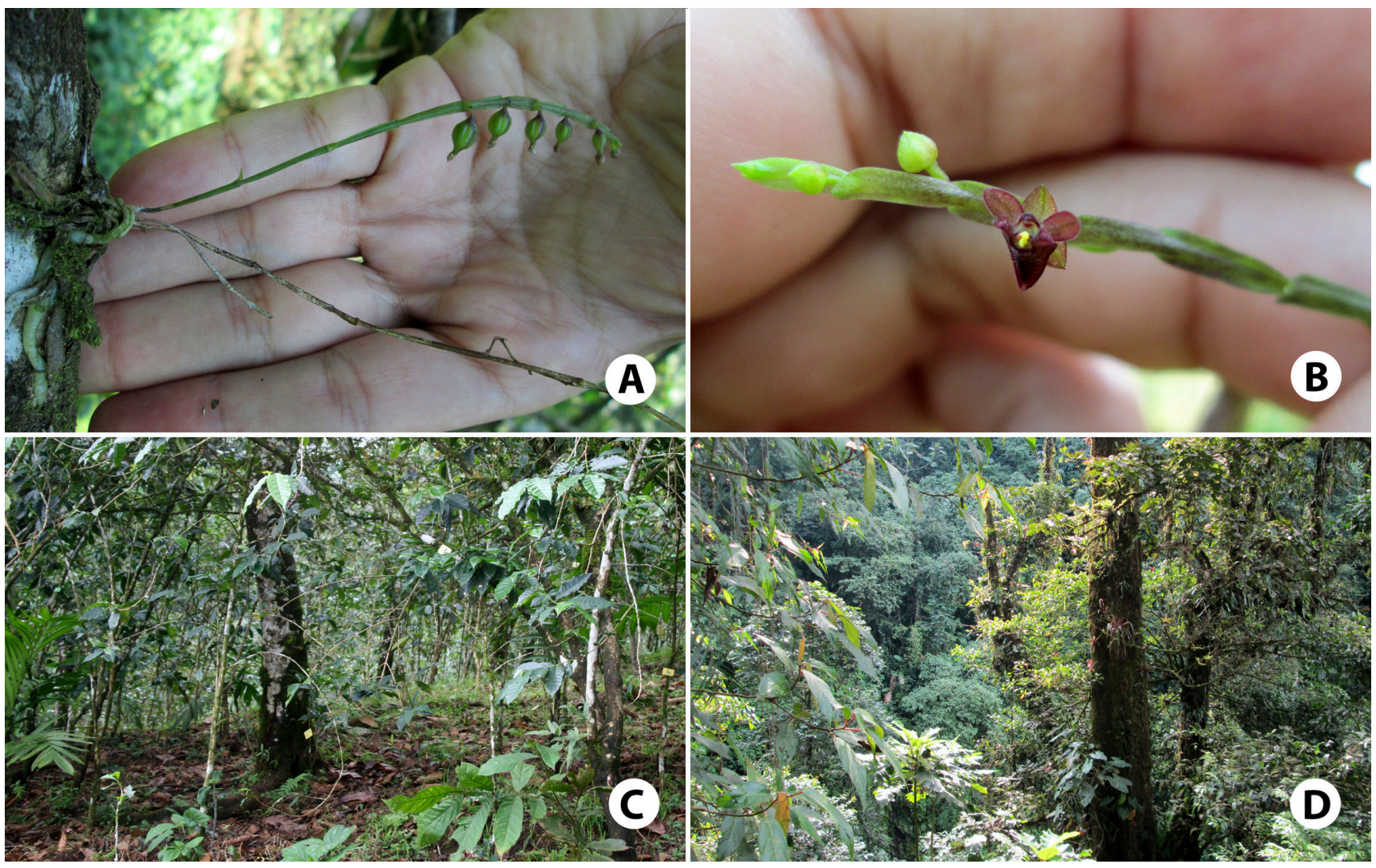

Figure 1. Telipogon helleri (Orchidaceae) and habitats in which the species is found in the area surrounding the rural community of Benito Juárez El Plan, in the region of Soconusco, Chiapas, Mexico. A: Adult individual with fruit; B: Adult individual in flower; C: Shaded coffee plantation where the species grows; D: Fragment of cloud forest where the species grows.

dangered (P), threatened (A) or subject to special protection (Pr) (SEMARNAT, 2010). The evaluation presented here is based on the data generated from the two known localities for T. helleri in Mexico.

Statistical analysis. Was compared the number of individuals of Telipogon helleri in each life stage per phorophyte and the number of individuals growing in different microsites on all phorophytes. To know the effect of the phorophyte and the life stage on the number of individuals, and to know the effect of the phorophyte and the microsite on the number of individuals we used a Generalized Lineal Models (GLM) analysis. In each case a Poisson distribution was used for the dependent variable (number of individuals) and the analysis was carried out using the software STATISTICA 8. In the case of the variable orientation of the orchid plants on the phorophytes, Rayleigh's Circular Uniformity test was applied, using the program Oriana (version 1.01). For descriptive statistics the mean and standard error were used.

\section{Results}

The new population of $\mathrm{T}$. helleri. It was discovered a new population of $T$. helleri growing in a cloud forest fragment in the outskirts of the community BJ (Locality 2), at approximately $2 \mathrm{~km}$ from the original locality. All the individuals were growing on a single phorophyte, situated in the centre of the forest fragment, and which was identified as Brunellia mexicana Standl. (Brunelliaceae; Table 1). This tree measuring $18 \mathrm{~m}$ in height and $28.65 \mathrm{~cm}$ in diameter. The population had 36 individuals of $T$. helleri, of which $38.89 \%$ were immatures and $61.11 \%$ adults (Table 1).

Phorophytes in the coffee plantation (original locality), number of individuals of $\mathrm{T}$. helleri and life stages. In the coffee plantation (Locality 1), T. helleri was found growing on six phorophytes, two of which were shade trees (chalum; Inga micheliana Harms; Fabaceae) and four coffee bushes (Coffea arabica). The trees averaged $5.75 \pm 0.25$ $\mathrm{m}$ in height and $31.43 \pm 4.21 \mathrm{~cm}$ in diameter, whereas the coffee bushes averaged $3.67 \pm 0.29 \mathrm{~m}$ in height and 4.52 $\pm 0.47 \mathrm{~cm}$ in diameter. A total of 78 individuals of $T$. helleri, were found, of which 12 were immatures and 66 were adults (Table 1). The number of individuals does not have the same distribution by life stage $\left(\chi^{2}=41.16, \mathrm{gl}=1, P<\right.$ $0.0001)$, neither between phorophytes $\left(\chi^{2}=43.97, \mathrm{gl}=5, P\right.$ $<0.0001)$. The phorophytes as well as the life stage explain part of the variation on the number of individuals of T. hel- 
Alfredo García-GonZÁlez et AL.

Table 1. Characterization of populations of Telipogon helleri (Orchidaceae) in two localities (Locality 1: coffee plantation; Locality 2: fragment of cloud forest), in the region of Soconusco, Chiapas, Mexico. Life stage; I: immatures, A: adults.

\begin{tabular}{|c|c|c|c|c|c|c|c|c|}
\hline \multirow{2}{*}{$\begin{array}{l}\text { Species of } \\
\text { phorophyte }\end{array}$} & \multirow{2}{*}{$\begin{array}{l}\text { No. of } \\
\text { phorophytes } \\
\text { for specie }\end{array}$} & \multirow{2}{*}{$\begin{array}{l}\text { No. of } \\
\text { individuals of } \\
\text { T. helleri }\end{array}$} & \multicolumn{4}{|c|}{ Vertical distribution of the orchids in each phorophyte } & \multicolumn{2}{|c|}{ No. orchids per life stage } \\
\hline & & & Trunk & Branch forks & Branches & Twigs & $\mathbf{I}$ & A \\
\hline \multicolumn{9}{|l|}{ Locality 1} \\
\hline Inga micheliana & 2 & 16 & 16 & 0 & 0 & ---- & 5 & 11 \\
\hline Coffea arabica & 4 & 62 & 1 & 0 & 4 & 57 & 7 & 55 \\
\hline Total & 6 & 78 & 17 & 0 & 4 & 57 & 12 & 66 \\
\hline \multicolumn{9}{|l|}{ Locality 2} \\
\hline Brunellia mexicana & 1 & 36 & 36 & 0 & 0 & 0 & 14 & 22 \\
\hline Combined total & 7 & 114 & 53 & 0 & 4 & 57 & 26 & 88 \\
\hline
\end{tabular}

leri, and there is an interaction between both factors $\left(\chi^{2}=\right.$ $12.03, \mathrm{gl}=2, P=0.002$ ). There were 16 individuals growing on I. micheliana, of which $31.25 \%$ were immatures and $68.75 \%$ adults. In the case of $C$. arabica phorophytes, there were 62 individuals, with $11.29 \%$ immatures and $88.71 \%$ adults (Table 1).

Vertical distribution and orientation of the individuals on the phorophytes. In Locality 2, $100 \%$ of the individuals were growing upon the trunk of the phorophyte. In Locality $1,21.79 \%$ were growing on the trunk, $5.13 \%$ on the branches, $73.08 \%$ on twigs and no individuals were found growing on the forks of the branches (Table 1). The number of individuals it is not distributed in the same way between microsites $\left(\chi^{2}=59.26, \mathrm{gl}=2, P<0.0001\right)$, or between phorophytes $\left(\chi^{2}=41.32, \mathrm{gl}=5, P<0.0001\right)$. The phorophyte as well as the microsite explain part of the variation in the number of individuals of Telipogon helleri, and there is an interaction between both factors $\left(\chi^{2}=73.12, \mathrm{gl}=4, P<\right.$ $0.0001)$. In the Inga micheliana phorophyte, T. helleri was only found on the trunks (Table 1).

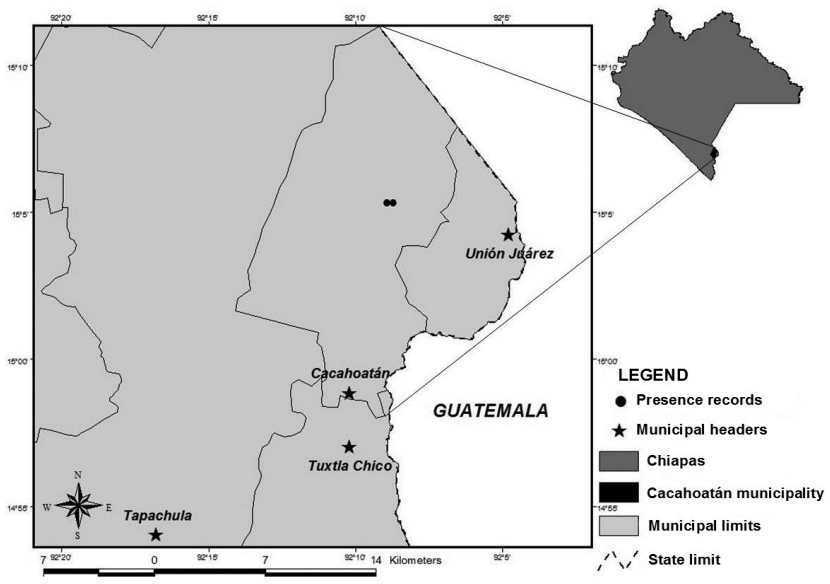

Figure 2. Localities for Telipogon helleri (Orchidaceae) in Chiapas, Mexico.
In Locality 1, despite the majority of individuals (13 individuals) growing facing southwest (Figure 3A), the cardinal orientation of the individuals on the phorophytes is similarly distributed (Rayleigh's Circular Uniformity test, $Z=0.316$, $P=0.729)$. Meanwhile, in Locality 2 , where the majority of individuals (25 individuals) were facing west (Figure 3B), there were significant differences in the cardinal orientation of the individuals (Rayleigh's Circular Uniformity test, $Z=$ 28.298, $P<0.001)$.

Telipogon helleri risk status. Based on the evaluation assigned to the indices proposed by the MER-Plantas.

\section{Rarity index.}

Value of criteria A: Characteristics of the geographical distribution.

Subcriteria A.1. The distribution extension. In Mexico, Telipogon helleri is only known from two localities, very close from each other (approximately $2 \mathrm{~km}$ ). Therefore, the amplitude of distribution of this species is greater than $1 \mathrm{~km}^{2}$ but less than $1 \%$ of the National Territory (ca. 2,000,000 km²); 3 points.

Subcriteria A.2. Number of known populations or localities. At present only two localities, which are close together, are known; 3 points.

Subcriteria A.3. Number of biogeographical provinces occupied by the taxon. According to the map of the biogeographical provinces of Mexico (CONABIO, 1997), Telipogon helleri is only found in one biogeographic province, Soconusco; 3 points.

Subcriteria A.4. Representativity of the distribution of the taxon within Mexican territory. Telipogon helleri has been reported in Nicaragua (Williams, 1962) and there are reports that it may be present in Costa Rica and Guatemala (Solano-Gómez et al., 2011), indicating that the distribution of this species in Mexico is peripheral or possibly outwith of its normal range; $\mathbf{1}$ point.

Total value of Criteria $A=0.9(10 / 11)$.

Value of criteria $B$ : Characteristics of the habitat. Subcriteria B.1. In how many types of vegetation is the tax- 

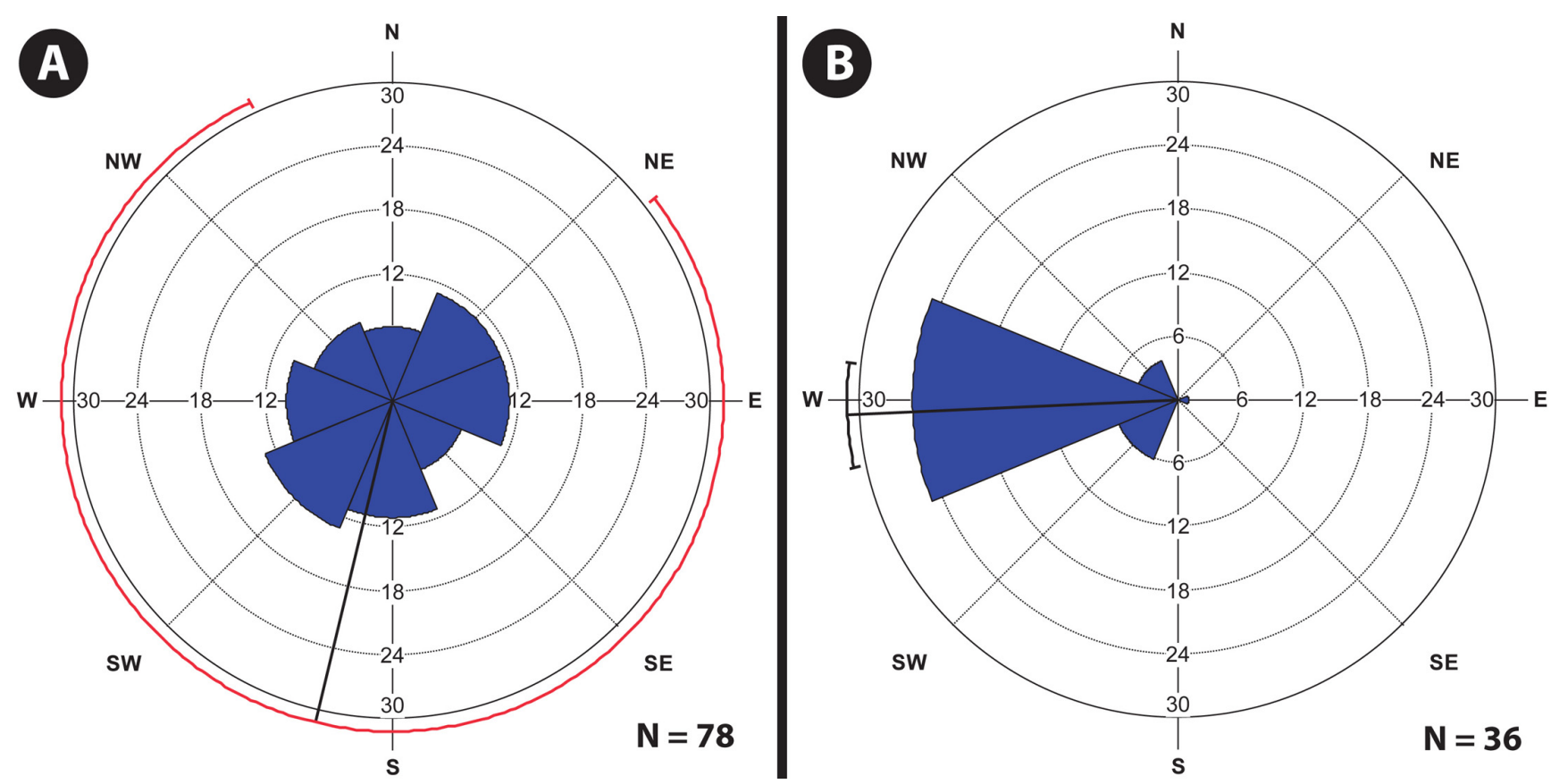

Figure 3. Rose diagrams of the cardinal orientation of individuals of Telipogon helleri (Orchidaceae) in Chiapas, Mexico. A: Locality 1 (coffee plantation); B: Locality 2 (cloud forest). The longest "petals" represent the most frequent orientations. Confidence intervals of $95 \%$.

on present? According to Rzedowski's (1990) map of Mexican potential vegetation, the two localities where Telipogon helleri has been found are situated on the boundry between regions classified as the pine-oak forest and tropical evergreen forest; 3 points.

Subcriteria B.2. Does the taxon have a specialized habitat? According to field observations, apparently Telipogon helleri prefers shaded forest understory with high atmospheric humidity, and cannot tolerate exposure to full sun. It grows on fairly rough textured trunks, branches and twigs with little moss and with few or no other epiphytes with which to compete. However, this orchid is probably not specialized as it is clearly sufficiently adapatable to grow in coffee plantations and cloud forest, and on a variety of phorophytes (Coffea arabica coffee bushes, Inga micheliana shade trees and the native forest tree Brunellia mexicana); 0 points.

Subcriteria B.3. The permanence of the population depends upon primary habitat? No, however, given the environmental preferences of the orchid, moderately or well conserved natural forest or shaded agroforestry habitats would be required; 0 points.

Subcriteria B.4. The permanence of the population requires a particular type of environmental disturbance or is associated with a transitory stage of succession? Populations of Telipogon helleri do not appear to require any particular type of disturbance or stage of succession; 0 points.

Subcriteria B.5. The amplitude of the altitudinal range occupied by the taxon. Taking into account the only confirmed report outside Mexico (Nicaragua; Williams, 1962) and the two localities in Mexico, the total range is from 1,100 to $1,499 \mathrm{~m}$, giving an amplitude of only $400 \mathrm{~m} ; 2$ points.

Total value of Criteria $B=0.55(5 / 9)$.

Value of the Criteria $C$ : Intrinsic biological vulnerability of the taxon.

Subcriteria C.1. Demography.

Subcriteria C.1.1. Total number of individuals. The total number of individuals of Telipogon helleri in the two localities is $114 ; 3$ points.

Subcriteria C.1.2. Recruitment. Although the results obtained by García-González and Damon (2013) suggested that Telipogon helleri growing in the coffee plantation could have a low recruitment rate, this new study indicates that in both localities there is recruitment; 0 points.

Subcriteria C.1.3. Demographic attributes. A) Is there evidence for density dependence in reproduction? No such evidence exists; 0 points. B) Is there evidence for clonality? Due to the morphological characteristics of the species (Solano-Gómez et al., 2011), it is unlikely that Telipogon helleri could propagate itself by the production of clones; 1 point. C) Is there evidence for population decline in Mexico? The taxon was only registered in Mexico in 2009 (Solano-Gómez et al., 2011), insufficient time to be able to measure population trends; 0 points. D) Is there evidence for a high degree of variability in fecundity? The results reported by García-González and Damon (2013) indicate limited variability: 35 adult individuals of T. helleri growing on the phorophyte Inga micheliana, with an average of $0.71 \pm 0.92$ fruits per individual, and nine adult individuals 
growing on Coffea arabica, with an average of $1.66 \pm 1.08$ fruits per individual; 0 points. E) Is the taxon dioecious, the individuals are dichogamous or autoincompatible? The species has functionally hermaphroditic flowers, but there is no available information regarding the reproductive system; 0 points. F) Flowering is synchronous or gregarious? Solano-Gómez et al. (2011) affirmed that T. helleri bloom between October and January, but in this study flowering was observed to continue until April. The extended flowering period observed, and few individuals present, preclude synchronous or gregarious flowering; 0 points. G) Does the taxon produce few propagules? The number of propagules produced for this species is unknown; $\mathbf{0}$ points.

Subcriteria C.2. Genetics. There is no available molecular information for the taxon and we could not evaluate $S u b$ criteria C.2.1. Molecular variation and Subcriteria C.2.2. Molecular genetic structure.

Subcriteria C.2.3. Quantity of genetic variation. The two known localities of Telipogon helleri are situated close together, although separated by a mountainous ridge and two small rivers, one each side of the ridge. The closeness possibly allow intercrossing between the two populations depending upon climatic factors and the behaviour of the pollinators. Furthermore it is possible that seeds may be dispersed from one locality to the other and viceversa, facilitating the eventual mixing of genes. Various authors suggest that orchid seeds do not travel long distances and tend to land close to the mother plant (Machon et al., 2003; Trapnell et al., 2004; Jersáková and Malinová, 2007; Winkler et al., 2009; Chung et al., 2011), but there are also reports in the literature of wider dispersal (Alcántara et al., 2006; Fay and Chase, 2009; Swarts et al., 2009). From the point of view of population genetics, even a low frequency of long distance dispersal events can effectively homogenize the genetic variation between populations (Chung et al., 2011). In the two localities the individuals are phenologically similar (size of plants, size of flowers, color etc.) and no pests and diseases have been observed. It would appear that there is low genetic variation between populations; 1 point.

Subcriteria C.2.4. Level of differentiation between populations. Although studies are needed to verify it, it is unlikely that there is a high level of differentiation between the two populations; 0 points.

Subcriteria C.3. Specialized biotic interactions.

Subcriteria C.3.1. Does the taxon require a "nurse plant"? No information or observations exist that would suggest that Telipogon helleri depends upon any particular type of "nurse plant" for its establishment; 0 points.

Subcriteria C.3.2. Does the taxon require a specific host or phorophyte? Telipogon helleri has been found growing upon three different phorophytes (Coffea arabica, Inga micheliana and Brunellia mexicana), suggest that specificity is unlikely; 0 points.
Subcriteria C.3.3. Does the taxon require a specific pollinator? Orchids of the genus Telipogon do not generally offer any reward to their pollinators (Dodson and Escobar, 1987), however, the flowers of many species often mimic the females of flies of the Tachinidae family, probably being pollinated by male flies of the same family (Dodson and Escobar, 1987; Dodson, 2003). Nevertheless, for the case of T. helleri, there is/are no known pollinator/s; 0 points.

Subcriteria C.3.4. Does the taxon require a specific dispersor? No, as for most orchid species, the minute seeds are dispersed by air currents (Arditti and Abdul Ghani, 2000; Hágsater et al., 2005) or perhaps on the plumage of birds (Arditti and Abdul Ghani, 2000); 0 points.

Subcriteria C.3.5. Does the taxon present obligate myrmecotrophy? Not present; 0 points.

Subcriteria C.3.6. Does the taxon present strict dependance on mycorrhizae? As for the majority of orchid species, Telipogon helleri needs to associate with mycorrhizal fungi to germinate, differentiate and develop (Hágsater et al., 2005; Jersáková and Malinová, 2007; Otero et al., 2007, Chung et al., 2011); 1 point.

Subcriteria C.3.7. Is the taxon severely affected by pests or pathogens? In neither locality were pests or pathogens observed, or competition with other species of flora; 0 points.

Total value of the Criteria $\mathrm{C}=0.26(6 / 23)$.

\section{Index of anthropogenic impact.}

Value of criteria $D$ : Impact of human activity on the taxon.

Subcriteria D.1. How does habitat disturbance affect the taxon? In the region where Telipogon helleri is found, various fragments of cloud forest still exist in different stages of succession and states of conservation, as well as extensive areas of coffee plantations with Inga micheliana as the principal shade tree. However, most of the fragments of cloud forest are small and found in relatively inaccessible ravines and valleys, whereas the more accessible fragments are indiscriminately deforested, causing landslides, forest structure loss, and the removal of potential phorophytes. Although most of the coffee plantations still retain shade trees, the trees diversity is low. Coffee plantations in the area are currently undergoing a series of drastic, economically motivated changes, which will have severe environmental consequences, which, however, have not yet been evaluated. Some of those changes are the systematic removal of moss and vascular epiphytes from the trunks and branches of the coffee bushes, the excessive pruning of shade trees, and the replacement of Coffea arabica plantations for robusta coffee (Coffea canephora Pierre ex A. Froehner; specie more resistant to rust attack, Hemileia vastatrix Berk. \& Broome; ITC, 2011). Over $C$. canephora few species of vascular epiphytes are able to grow; 1 point.

Subcriteria D.2. What is the level of impact of human activities upon the habitat of the taxon? The anthropogenic 
disturbance cited above impacts strongly on the ecosystems in the region, including the cloud forests and coffee plantations where Telipogon helleri is found. Specifically, in the coffee plantation of Locality 1 , the moss and vascular epiphytes have not been removed, although the phenomena is observed in all neighboring plots, which may limit the possibilities for extension of the population of T. helleri. Meanwhile, the forest fragment of Locality 2 has suffered excessive logging and consequent landslides, although it still maintains several large trees; $\mathbf{3}$ points.

Subcriteria D.3. Does evidence exist that indicates deterioration of the quality or extension of the habitat, such as climate change, or is a major change of land use predicted? All of the natural ecosystems in Soconusco have been affected by deforestation (Sánchez and Jarquín, 2008) and the whole area is under pressure as a result of a human population density of $121.3 \mathrm{inhab} / \mathrm{km}^{2}$, which is more than double the state average of $51.8 \mathrm{inhab} / \mathrm{km}^{2}$ (Rojas-Wiesner et al., 2004). The Soconusco region is dominated by coffee plantations (Sánchez and Jarquín, 2008), which were developed towards the end of the XIX century (Altamirano-González-Ortega et al., 2011) and although coffee continues to be one of the principal products of the región, pests and diseases, ageing plantations, low productivity, erosion and market fluctuations threaten the activity. The area has also been severely affected by inadequate techniques for the opening and maintenance of roads, causing extensive landslides (Damon and Colín-Martínez, 2005). However, there are no current measurements, predictions or models to quantify the magnitude of the environmental changes in the region; $\mathbf{0}$ points.

Subcriteria D.4. What is the impact of exploitation of the taxon? Telipogon helleri is not considered as an ornamental plant and there are no reports of traditional uses; 0 points.

Subcriteria D.5. The taxon is cultivated or propagated ex situ? At present Telipogon helleri is not being propagated or cultivated; 0 point.

Total value of Criteria $\mathrm{D}=0.4(4 / 10)$.

Sum of the values obtained for the criteria considered, A: $0.9+$ B: $0.55+$ C: $0.26+$ D: $0.4=2.11$ points.

\section{Discussion}

The discovery of a new locality of Telipogon helleri is important for the conservation of this species in Mexico. This population grows in a cloud forest fragment, which according to Hágsater et al. (2005) it is the habitat for $60 \%$ of the orchids in Mexico, making the conservation of this ecosystem of vital importance. This new population, despite being located very close to the only other known locality of $T$. helleri (Locality 1), reported by Solano-Gómez et al. (2011), extends the species distribution area and places it in a new habitat. Also, the new population shows a ratio of immature individuals/adult individuals, indicating recruitment, which is a vital factor for the conservation of this species.
In 2009 the only known population of Telipogon helleri in Mexico grew exclusively in a shade coffee plantation and had 46 individuals (García-González and Damon, 2013). In this plantation, five years later, the panorama is different and the population has increased $1.7 \%$, counting at present with 78 individuals. During this period, both the number and the proportion of immature and adult individuals have changed. In 2009, the immature individuals represented $2.17 \%$ of the population (one individual; García-González and Damon, 2013), compared to $15.38 \%$ in 2014. Meanwhile, the proportion of adult individuals has dropped from $97.83 \%$ of the population (45 individuals; García-González and Damon, 2013) to $84.62 \%$ at present. The age structure is still dominated by adults, thus promoting the maintenance of the species, since adults produce the propagules for the next generation and this stage is considered the most important in orchids life (Zotz, 1998; Winkler and Hietz, 2001; Mondragón, 2009). The population has increased and there is now clear evidence of new recruitment.

Regarding the phorophytes, in 2009, $78.26 \%$ of the population (36 individuals) of Telipogon helleri was found on two shade trees of Inga micheliana, and 21.74\% (10 individuals) was growing on a single coffee bush phorophyte (GarcíaGonzález and Damon, 2013). This evaluation shows that the situation has reversed, with $79.49 \%$ of the present population now growing on four Coffea arabica bushes with an increase of 10 to 30 individuals on the original coffee bush. There are now fewer individuals growing on the two I. $\mathrm{mi}$ cheliana shade trees, with only $20.51 \%$ of the population growing on that phorophyte; in one tree the number of individuals has decreased from 35 to four, whereas there was an increase from one to 14 on the other tree.

Coffee bushes are often seen to be good phorophytes for epiphytes in general, and in particular, the thin terminal branches are host to a range of miniature, twig epiphytes such as the genera Erycina Lindl. and Notylia Lindl. (Hágsater et al., 2005; Damon and Valle-Mora, 2008; Pérez-Hernández et al., 2011), and the oldest bushes are often host to rare orchid species that cannot be found elsewhere (Hágsater et al., 2005). García-González and Damon (2013) proposed that the coffee plantation could be acting as a temporary refuge or that Telipogon helleri could be adapting permanently to life in this agroecosystem. The results of this study seem to confirm the second option.

The loss of a significant number of individuals from one of the Inga micheliana shade trees in a period of five years is probably related to an increase in the covering of moss on the trunk of this phorophyte and Telipogon helleri may prefer substrates where it does not have to compete with bryophytes. The other tree which was previously occupied in the plantation now has a larger number of $T$. helleri plants, but nearly all appear to be unhealthy and several are apparently dying, probably due to recent pruning of the phorophyte. 
The microhabitats occupied by Telipogon helleri have also changed in the five year period between evaluations, mostly in the case of the Coffea arabica phorophytes. Originally, $73.92 \%$ of the entire population was growing on the trunks of the shade tree or coffee phorophytes (García-González and Damon, 2013), whereas in this study more than $70 \%$ were growing on twigs. Possibly, this microsite is more appropriate for the ecological requirements and typical morphological features of T. helleri, and although individuals are not in the trunk, which is usually the more protected and wetter section of phorophyte, anyway the individuals keep under shady conditions provided by the shade trees, that in this plot have an average height of $6.24 \pm 2.03 \mathrm{~m}$ (GarcíaGonzález and Damon, 2013), while T. helleri grows to an average height of $1.89 \pm 0.06 \mathrm{~m}$.

In the cloud forest fragment of the new locality, the canopy is more closed, with less light reaching the understory than in the coffee plantation and all individuals of Telipogon helleri grow below a height of $2 \mathrm{~m}$. However, the phorophyte is situated close to a small path, so that the orchids receive more light than inside the forest.

Considering the cardinal points, in the coffee plantation the species do not show a clear trend, although $16.67 \%$ of Telipogon helleri individuals grow southwest oriented. However, in 2009, $45.65 \%$ of individuals (21 individuals) were located to the northeast (García-González and Damon, 2013) and currently at that position it is only oriented 14.1 $\%$ of individuals. All the assumptions of the population five years ago are mainly based on the 36 individuals growing on Inga micheliana and the biggest part was oriented in that direction (García-González and Damon, 2013). However, due to the small size and the concentration of population, it was difficult to see trends. Currently, although this population remains small, it has almost twice and has also spread to other phorophytes, making it easier to deduce ecological preferences and hypothesize about future scenarios.

Tremblay and Velázquez-Castro (2009) found that in Lepanthes eltoroensis Stimson, the distribution pattern was not uniform, and orchids were oriented towards many directions, with a slight preference for northwest orientation, possibly due the constant winds which characterize the habitat, and which also form part of the ecological requirements of these orchids. Similarly, the direction and speed of the winds in the localities occupied by Telipogon helleri, may influence the successful germination and establishment of plants from seeds randomly landing on the different, available microsites, and the influence exerted may also shift with time.

However, according to Callaway et al. (2002), water availability is also a key factor in the establishment of epiphytes on phorophytes. It is therefore possible that the two small rivers located close to the populations of Telipogon helleri (one on each side of the mountainous ridge), may contribute to preferences for certain cardinal directions in the phorophytes, due to a slight increase in moisture, but enough to enable $T$. helleri to establish more readily (Rech et al., 2011). In Locality 1, regardless of the phorophyte, $65.38 \%$ of individuals of $T$. helleri faced towards the east, southeast, south, southwest or west, while in Locality 2, $86.11 \%$ of individuals were oriented towards the southwest or west of the only phorophyte, always the cardinal points of phorophytes which are located of front or parallel to the course of small rivers. Similarly, Telipogon nirii Ackerman, a very rare species, endemic to the Dominican Republic, and morphologically very similar to $T$. helleri, always grows in wet mountain, epiphytic on trees overhanging rivers (Ackerman, 2014).

The conservation state of of Telipogon helleri outside of Mexico is unknown, with only one confirmed report of the species in Nicaragua, and no further information (Williams, 1962). This could imply that the species is rare, or that it is simply constantly overlooked due to its small size. However, rigorous searching in the region where T. helleri has been found has not revealed more populations and it is safe to suggest that in Mexico, at least, the species should be considered endangered $(\mathrm{P})$, which is confirmed by the score obtained with the sum of the MER-Plantas four criteria, and due to having less than 500 individuals (SEMARNAT, 2010). We consider it a priority the inclusion of this species in the NOM-059-SEMARNAT-2010 (Mexican Official Standard) which includes the species of wild plants and animals considered to be in one of the different categories of risk in the country (SEMARNAT, 2010). However, this process takes time and $T$. helleri has only recently been registered in Mexico.

The MER-Plantas is a useful methodology used to evaluate different taxa of Mexican flora. For example, in an orchid species Stelis zootrophionoides Castaneda-Zarate \& Ramos-Castro, the sum of the four evaluation criteria (A, $\mathrm{B}, \mathrm{C}$ and $\mathrm{D}$ ) of this method permitted to consider this species as in endangered (P; García-González et al., 2015), this score is similar to punctuation obtained to Telipogon helleri in this study. In the case of five species of agaves of Polianthes L. genera, listed in the category of special protection (Pr) in NOM-059-ECOL-2001, their punctuation permitted to reclassify their conservation status: Polianthes densiflora (B.L. Rob. \& Fernald) Shinners and P. howardii Verh.-Will. were classified as in endangered $(\mathrm{P}), P$. longiflora Rose and P. platyphylla Rose were reclassified as threatened (A) and P. palustris Rose were considered probably extinct (FeriaArroyo et al., 2010). Meanwhile the assessment of Mammillaria pectinifera F.A.C. Weber (Cactaceae) suggest that this species should consider as endangered $(\mathrm{P})$ while in NOM059-ECOL-2001 it classify as threatened species (A; Valverde et al., 2009).

The values assigned to each of the criteria of the MERPlantas, are susceptible to change as the knowledge about this specie increases; nonetheless, this does not necessarily 
imply a substantial change in the Telipogon helleri status (Valverde et al., 2009). This species presents high biological vulnerability, the total number of individuals is very low, and these are concentrated only in seven phorophytes, present in only two localities very near each other, both of which are subject to human intervention.

Despite the increase in the number of individuals of Telipogon helleri in the original locality (Locality 1) and the discovery of second population (Locality 2), there is a total of only 114 individuals recorded in Mexico (Table 1), and it is mandatory to continue monitoring these populations to determine whether the rate of recruitment continues to exceed that of mortality. This type of tracking of the demographic behaviour in disturbed areas is particularly important to ensure successful management of the species in the long term (Octavio-Aguilar et al., 2008).

Also, considering that studies of the allelic structure of wild populations is highly recommended and this information permits predictions as to whether a species is capable of adapting to environmental change (González-Astorga et al., 2003); it should be a priority to conduct molecular studies to assess the level of endogamy and genetic diversity of the individuals of these very small populations of Telipogon helleri, which will have important implications for the conservation of this species (Chung et al., 2011).

\section{Acknowledgements}

We thank Nelson Pérez Miguel for valuable collaboration in the field, to Neptalí Ramírez Marcial for help with the confirmation of the identification of the phorophyte Brunellia mexicana, and the anonymous reviewers for their valuable recommendations. We are grateful to the organization Idea Wild for various pieces of equipment which were fundamental for the carrying out of this study.

\section{Literature cited}

Ackerman J.D. 2014. Telipogon. In: Ackerman J.D. Coor. Orchid flora of the Greater Antilles, pp. 496-497, Memoirs of the New York Botanical Garden, Vol. 109, The New York Botanical Garden Press, New York.

Alcántara S., Semir J. and Solferini V.N. 2006. Low genetic structure in an epiphytic Orchidaceae (Oncidium hookeri) in the Atlantic rainforest of south-eastern Brazil. Annals of Botany 98:1207-1213.

Altamirano-González-Ortega M.A., Enríquez-Rocha P., RangelSalazar J.L., García-Estrada C. and Tejeda-Cruz C. 2011. La ruta del café y la diversidad de las aves. Biodiversitas 96:11-16.

Arditti J. and Abdul Ghani A.K. 2000. Tansley Review No. 110. Numerical and physical properties of orchid seeds and their biological implications. New Phytologist 145:367-421.

Arriaga L., Espinoza J.M., Aguilar C., Martínez E., Gómez L. and Loa E. Coors. 2000. Regiones terrestres prioritarias de México. Comisión Nacional para el Conocimiento y Uso de la Biodiver- sidad. <http://www.conabio.gob.mx/conocimiento/regionalizacion/doctos/Tlistado.html> (accessed March 9, 2014).

Callaway R.M., Brooker R.W., Choler P., Kikvidze Z., Lortie Ch.J., Michalet R., Paolini L., Pugnaire F.I., Newingham B., Aschehoug E.T., Armas C., Kikodze D. and Cook B.J. 2002. Positive interactions among alpine plants increase with stress. Nature 417:844-848.

Chung M.Y., Nason J.D. and Chung M.G. 2011. Significant demographic and fine-scale genetic structure in expanding and senescing populations of the terrestrial orchid Cymbidium goeringii (Orchidaceae). American Journal of Botany 98:2027-2039.

CONABIO [Comisión Nacional para el Conocimiento y Uso de la Biodiversidad]. 1997. Provincias biogeográficas de México, map scale 1: 4,000,000. Comisión Nacional para el Conocimiento y Uso de la Biodiversidad. <http://www.conabio.gob.mx/informacion/gis/layouts/rbiog4mgw.png $>$ (accessed April 3, 2014).

Damon A. and Colín-Martínez H. 2005. El estado actual de las poblaciones de orquídeas en la Región del Soconusco, Chiapas, México. Amaranto 17:2-16.

Damon A. and Valle-Mora J. 2008. Retrospective spatial analysis of the pollination of two miniature epiphytic orchids with different pollination strategies in a coffee plantation in Soconusco, Chiapas, Mexico. Botanical Journal of the Linnean Society 158:448-459.

Dillon G. 1977. Respuesta de la American Orchid Society al proyecto de ley sobre especies en peligro. Sociedad Venezolana de Ciencias Naturales. Comité de Orquideología 16:14-18.

Dodson C.H. 2003. Why are there so many orchid species? Lankesteriana 7:99-103.

Dodson C.H. and Escobar R. 1987. The Telipogons of Costa Rica (I). Orquideología 17:3-69.

Espejo-Serna A., López-Ferrari A.R., Jiménez-Machorro R. and Sánchez-Saldaña L. 2005. Las orquídeas de los cafetales en México: una opción para el uso sostenible de ecosistemas tropicales. Revista de Biología Tropical 53:73-84.

Fay M.F. and Chase M.W. 2009. Orchid biology: from Linnaeus via Darwin to the 21st century. Annals of Botany 104:359-364.

Feria-Arroyo T.P., Solano E. and García-Mendoza A. 2010. Reevaluación del riesgo de extinción de cinco especies del género Polianthes L. (Agavaceae). Acta Botanica Mexicana 92:11-28.

García-González A. and Damon A. 2013. Abundancia, distribución en los forófitos y producción de frutos de la primera población de Telipogon helleri (Orchidaceae) descubierta en México. Revista Mexicana de Biodiversidad 84:894-900.

García-González A. and Pérez-Márquez R. 2011. La comunidad orquideológica en la Reserva de la Biosfera Sierra del Rosario, Cuba. Revista de Biología Tropical 59:1805-1812.

García-González A., Damon A., Esparza-Olguín L.G. and ValleMora J. 2011. Population structure of Oncidium poikilostalix (Orchidaceae), in coffee plantations in Soconusco, Chiapas, México. Lankesteriana 11:23-32.

García-González A., Riverón-Giró F.B., Solano-Gómez R., Aguilar-Romero O. and Martínez-Ovando E. 2015. Nuevas localidades y formas florales del endemismo mexicano Stelis zootrophionoides (Orchidaceae), y evaluación de su riesgo de extinción. Botanical Sciences 93:865-875.

González-Astorga J., Vovides A.P., Ferrer M.M. and Iglesias C. 2003. Populations genetics of Dioon edule Lindl. (Zamiaceae, Cycadales): biogeographical and evolutionary implications. Biological Journal of the Linnean Society 80:457-467. 
Hágsater E., Soto-Arenas M.A., Salazar-Chávez G.A., JiménezMachorro R., López-Rosas M.A. y Dressler R.L.2005. Las orquídeas de México. Instituto Chinoín. Mexico City.

IUCN and OSG. 2012. International Union for Conservation of Nature and Orchid Specialist Group.<http://www.iucn. org/about/work/programmes/species/who_we_are/ssc_specialist_groups_and_red_list_authorities_directory/plants/orchid_specialist_group/about_orchids/> (accessed September 5, 2014).

ITC. 2011. The coffee exporter's guide. International Trade Centre, Geneva. <http://www.intracen.org/The-Coffee-ExportersGuide---Third-Edition/> (accessed October 28, 2015).

Jersáková J. and Malinová T. 2007. Spatial aspects of seed dispersal and seedling recruitment in orchids. New Phytologist 176:237-240.

Machon N., Bardin P., Mazer S.J., Moret J., Godelle B. and Austerlitz F. 2003. Relationship between genetic structure and seed and pollen dispersal in the endangered orchid Spiranthes spiralis. New Phytologist 157:677-687.

Moguel P. and Toledo V.M. 1999. Review: Biodiversity conservation in traditional coffee systems of Mexico. Conservation Biology 13:11-21.

Mondragón D. 2009. Population viability analysis for Guarianthe aurantiaca, an ornamental epiphytic orchid harvested in Southeast México. Plant Species Biology 24:35-41.

Octavio-Aguilar P., González-Astorga J. and Vovides A.P. 2008. Population dynamics of the Mexican cycad Dioon edule Lindl. (Zamiaceae): life history stages and management impact. Botanical Journal of the Linnean Society 157:381-391.

Otero J.T., Flanagan N.S., Herre E.A., Ackerman J.D. and Bayman P. 2007. Widespread mycorrhizal specificity correlates to mycorrhizal function in the Neotropical, epiphytic orchid Ionopsis utricularioides (Orchidaceae). American Journal of Botany 94:1944-1950.

Pérez-Hernández H., Damon A., Valle-Mora J. and Sánchez-Guillen D. 2011. Orchid pollination: specialization in chance? Botanical Journal of the Linnean Society 165:251-266.

Rech A.R., Rosa Y.B.C.J. and Rosa-Junior E.J. 2011. Levantamento e características ecológicas de Orchidaceae da mata ciliar do Rio Dourados, Dourados-MS. Revista Árvore 35:717-724.

Rojas-Wiesner M.L., Ángeles-Cruz H.M., Sánchez-Vázquez J.E., Infante-Martínez F., Holguín-Meléndez F., Castro-Castro V., Sokolov-Mikhail Y. and Tovilla-Hernández C. 2004. Breve diagnóstico del Soconusco. El Colegio de la Frontera Sur (ECOSUR), Tapachula.

Rzedowski J. 1990. Vegetación potencial, map scale 1: 4,000,000, IV.8.2. Atlas Nacional de México, Sección Naturaleza, vol. II. Instituto de Geografía, Universidad Nacional Autónoma de México, Mexico City. <http://www.conabio.gob.mx/informacion/gis/layouts/vpr4mgw.png > (accessed June 10, 2014).

Sánchez J.E. and Jarquín R. Eds. 2008. La Frontera Sur. Reflexiones sobre el Soconusco, Chiapas, y sus problemas ambientales, poblacionales y productivos. Senado de la República, Comisión de Biblioteca y Asuntos Editoriales and El Colegio de la Frontera Sur (ECOSUR), Tapachula.

SEMARNAT. 2010. Mexican Official Standard NOM-059-SEMARNAT-2010. Protección ambiental-Especies nativas de México de flora y fauna silvestres-Categorías de riesgo y especificaciones para su inclusión, exclusión o cambio-Lista de especies en riesgo. Secretaria de Medio Ambiente y Recursos Naturales, Mexico. Diario Oficial de la Federación, second section, December 30, 2010. <http://www.profepa.gob.mx/innovaportal/file/435/1/ NOM_059_SEMARNAT_2010.pdf> (accessed April 3, 2014).

SEMARNAT and CONANP. 2013. Programa de Manejo Reserva de la Biosfera Volcán Tacaná. Secretaría de Medio Ambiente y Recursos Naturales and Comisión Nacional de Áreas Naturales Protegidas, Mexico City.

Solano-Gómez R., Damon A., Cruz-Lustre G., Jiménez-Bautista L., Avendaño-Vázquez S., Bertolini V., Rivera-García R. and Cruz-García G. 2016. Diversidad y distribución de las orquídeas de la región Tacaná-Boquerón, Chiapas, México. Botanical Sciences (in press).

Solano-Gómez R., Jiménez-Machorro R. and Damon A. 2011. Two new records and one rediscovery for Orchidaceae of Mexico. Acta Botanica Mexicana 96:59-72.

Soto-Arenas M.A., Hágsater E., Jiménez-Machorro R., SalazarChávez G.A., Flores-González R. and Ruiz-Contreras I. 2007. Las Orquídeas de México: Catalogo Digital (CD-ROM). Herbario AMO. Instituto Chinoín, Mexico City.

Swarts N.D., Sinclair E.A., Krauss S.L. and Dixon K.W. 2009. Genetic diversity in fragmented populations of the critically endangered spider orchid Caladenis huegelii: Implications for conservation. Conservation Genetics 10:1199-1208.

Trapnell D.W., Hamrick J.L. and Nason J.D. 2004. Three-dimensional fine-scale genetic structure of the neotropical epiphytic orchid Laelia rubescens. Molecular Ecology 13:1111-1118.

Tremblay R.L. and Velázquez-Castro J. 2009. Circular distribution of an epiphytic herb on trees in subtropical rain forest. Tropical Ecology 50:211-217.

Valverde P.L., Zavala-Hurtado J.A., Jiménez-Sierra C., RendónAguilar B., Cornejo-Romero A., Rivas-Arancibia S., LópezOrtega G. and Pérez-Hernández M.A. 2009. Evaluación del riesgo de extinción de Mammillaria pectinifera, cactácea endémica de la región de Tehuacán-Cuicatlán. Revista Mexicana de Biodiversidad 80:219-230.

Williams L.O. 1962. Tropical American Plants IV. Brittonia 14:443-446.

Winkler M., Hülber K. and Hietz P. 2009. Population dynamics of epiphytic orchids in a metapopulation context. Annals of Botany 104:995-1004.

Winkler M. and Hietz P. 2001. Population structure of three epiphytic orchids (Lycaste aromatica, Jacquiniella leucomelana, and J. teretifolia) in a Mexican humid montane forest. Selbyana 22:27-33.

Zotz G. 1998. Demography of the epiphytic orchid, Dimerandra emarginata. Journal of Tropical Ecology 14:725-741.

Received: October 15th, 2014

Accepted: January 31st, 2015 